\title{
NUTRITIVE VALUE OF EKOFISH MEAL IN PIG NUTRITION **
}

\section{B. Živković ${ }^{1 *}$, W. Migdal $^{3}$, V. Veselinović ${ }^{2}, \check{C}^{\text {C. Radović }}{ }^{1}$, M. Fabjan ${ }^{1}$, O. Kosovac $^{1}$}

${ }^{1}$ Institute for Animal Husbandry, Belgrade-Zemun, Serbia

${ }^{2}$ Bankom, New Belgrade, Serbia

${ }^{3}$ Akademia Rolnicza, Kraków. Poland.

Corresponding author: *Branislav D. Živković; e mail: zivkovicbbranislav@yahoo.com

** Original scientific paper - Originalana naučni rad

Research was financed by the Ministry of Science of Republic of Serbia within project TR 20087

- Rad je finansiran od strane Ministarstva za nauku Republike Srbije u okviru projekta TR 20087

Abstract: The effects of utilization of high protein feedstuff of plant origin- Ekofish meal, domestic product, in nutrition of lactating sows and suckling piglets were investigated.

Considering our previous positive experiences in the use of similar feedstuffs in nutrition of weaned piglets and fattening pigs also the application of Ekofish meal as a substitute of fish meal in pig nutrition, objective of this paper was to evaluate the effects of the utilization of Ekofish meal in iso-energy and iso-nitrogen diets for lactating sows and suckling piglets. Investigated feedstuff was produced according to specific technology in production plant of the company Bankom in Serbia.

Research was carried out on experimental pig farm of the Institute for Animal Husbandry, Belgrade-Zemun, Serbia.

Obtained results have shown that, the introduction of investigated feedstuff had a positive effects expressed through shorter service period by 2.4 feeding days, better gain by $4.52 \%$ in suckling piglets, increased the intake of pre-starter by $1.0 \mathrm{~kg} /$ litter in piglets during creep feeding.

In general, the obtained results have shown that utilization of Ekofish meal as high protein feedstuff can be recommended in nutrition of sows and piglets. The effects of utilization of high protein feedstuff of plant originEkofish meal, domestic product, in nutrition of lactating sows and suckling piglets were investigated.

Key words: Ekofish meal, sows, suckling piglets. 


\section{Introduction and literature review}

Based on the decision of the EU Commission 9/2001, the mixtures containing fish meal can only be produced in feed mills which don't produce or process feeds for ruminants or are specialized for this purpose with license from authorized institutions (Sardi et al. 2005). This fact leads to increasing the opposition of consumers in regard to utilization of animal proteins in livestock feed which justifies further research of the possibility to exclude fish meal from mixtures for pigs.

Considering our previous the positive experiences in utilization of feedstuff under trade name Vitaprotein 50 imported from Belgium (Hoorick van. 2003) in the nutrition of weaned piglets (Živković et al.. 2007) and fattening pigs (Živković et al.. 2006) which has similar nutritive characteristics as Ekofish meal used in nutrition of weaned piglets (Adamović et al.. 2006) and our earlier the positive experience with Ekofish meal as a supstute of fish meal in the nutrition of sows and suckling piglets (Živković et al., 2007) and weaned piglets (Živković et. Al., 2007) and, objective of this paper was to evaluate the effect of utilization of Ekofish meal based on plant protein sources in the isoenergy and iso-protein diets for lactating sows and suckling piglets.

Investigated feedstuff was produced according to specific technology in production plants of company Bankom in Serbia.

\section{Material and methods}

Investigations were carried out on Experimental pig farm of the Institute for Animal Husbandry, Belgrade-Zemun. Trial included total of 22 sows, divided into two feeding treatments. Criteria for their distribution were the origin, the parity and the boars used for their insemination.

Approximately 10 days prior to farrowing all pregnant sows were transferred into farrowing department. Sows of the first - control and second trial groups were fed mixtures for lactating sows and investigated feedstuff (table 1) was included into experimental mixture. In all compared mixtures the energy and protein levels were equal (table 2), and sows during lactation were fed individually and for the suckling piglets in the groups, the feeding was ad libitum.

Subsequent to farrowing, the creep feeding of piglets at the age of 8 days started with two mixtures, in control group without investigated feedstuff Ekofish meal and in trial group with investigated feedstuff. (table 3). Animals received meal mixtures and water ad libitum. 
Table 1. Scheme of the experiment

Tabela 1. Šema eksperimenta

\begin{tabular}{|c|c|c|}
\hline Group - Grupa & $\begin{array}{c}1 \\
\text { control - kontrolna }\end{array}$ & $\begin{array}{c}2 \\
\text { experimental - } \\
\text { ogledna }\end{array}$ \\
\hline \multicolumn{3}{|l|}{ Lactating sows - Krmače u laktaciji } \\
\hline $\begin{array}{l}\text { Ekofish meal during lactation in the diet } \\
\text { Ekofiš meal tokom laktacije } \mathrm{u} \text { obroku }\end{array}$ & - & + \\
\hline Feed/head/day - Hrane/grlo/dan & ad libitum-po volji & ad libitum-po volji \\
\hline \multicolumn{3}{|c|}{ Suckling piglets-creep feeding - Prasad na sisi -prihranjivanje } \\
\hline $\begin{array}{l}\text { Ekofish meal during lactation in the diet } \\
\text { Ekofiš meal tokom laktacije u obroku }\end{array}$ & - & + \\
\hline Feed/head/day - Hrane/grlo/dan & ad libitum-po volji & ad libitum-po volji \\
\hline
\end{tabular}

For evaluation of the obtained results the following indicators were used: body mass of sows prior to farrowing and at weaning, feed intake during lactation, the number of equalized live born piglets at farrowing, average body mass of piglets at birth and weaning, average daily gain of piglets during the lactation.

Table 2. Nutritive value of Ekofish meal used in the experiment

Tabela 2. Nutritivna vrednost Ekofiš meala korišćenog u ogledu

\begin{tabular}{|l|c|}
\hline Metabolizable energy. MJ/kg - Metabolička energija, MJ/kg & 13.80 \\
\hline Moisture. \% - Vlaga, \% & 8.0 \\
\hline Crude protein. \% - Sirovi protein, \% & 60.0 \\
\hline Ether extract. \% - Sirove masti, \% & 5.0 \\
\hline Crude fiber. \% - Sirova celuloza, \% & 3.0 \\
\hline Ash. \% - Pepeo, \% & 4.0 \\
\hline Calcium. \% - Kalcijum, \% & 0.90 \\
\hline Phosphorus total. \% - ukupni fosfor, \% & 0.54 \\
\hline Sodium. \% - Natrijum, \% & 0.16 \\
\hline Some of Essential Amino Acids. g/16 gN - Neke od esencijalnih amino kiselina, g/protein : \\
\hline Lysine - Lizin & 7.83 \\
\hline Methionine + cystine - Metionin + cistin & 4.02 \\
\hline Tryptophane - Triptofan & 1.08 \\
\hline Threonine - Treonin & 3.98 \\
\hline
\end{tabular}


Obtained results in regard to the gain in piglets were processed statistically by variance analysis and differences between average values by ttest.

Table 3. The scheme of the nutrition of the experiment

Tabela 3. Šema ishrane u ogledu

\begin{tabular}{|l|c|c|}
\hline & Sows - Krmače & $\begin{array}{c}\text { Suckling piglets - } \\
\text { Prasad na sisi }\end{array}$ \\
\cline { 2 - 3 } & $\begin{array}{c}\text { Lactation - } \\
\text { Laktacija }\end{array}$ & $\begin{array}{c}\text { Creep feeding - } \\
\text { Prihranjivanje }\end{array}$ \\
\hline $\begin{array}{l}\text { Crude protein, \% in diets-Sirovi protein u } \\
\text { smešama, \% }\end{array}$ & 18.0 & 22.0 \\
\hline $\begin{array}{l}\text { Ekofish meal in the experimental diets, \% - } \\
\text { Učešce Ekofish meala u oglednim smešama, \% }\end{array}$ & 2.0 & 5.0 \\
\hline
\end{tabular}

The feeds used in the diets: corn, wheat midllings, soybean oil meal, sunflower oil meal, domestic plant high protein feedstuff - Ekofish meal, milk replacer for piglets - ekolak, full fat soybean, limestone, mono-calcium phosphate, salt, vitamin-mineral pre-mixture, L-lysine $\mathrm{HCl}$

\section{Results and discussion}

In this trial, the possibility for introduction of domestic high protein feedstuff of plant origin - Ekofish meal in the nutrition for lactating sows and suckling piglets was investigated.

Obtained results (table 4) showed that the sows in control group fed diets without Ekofish meal during the lactation lost $15.23 \%$ of their own body mass. There was no significant difference in loss of body mass in compared the experimental group of sows. After weaning, average service period for the control group of sows was 9.8 days to first insemination, and in the trial group the average service period was only 7.4 days, which is shorter by 2.4 days feeding days.

In regard to feed intake of the sows during lactation (table 4) using the control mixture without Ekofish meal, average daily feed intake of $3.76 \mathrm{~kg}$ was realized. Introduction of investigated protein feedstuff - Ekofish meal into the mixture during the lactation caused the slight decrease of feed intake in average by $0.10 \mathrm{~kg}$ or $2.73 \%$ compared to the control group. 
Table 4. Performance of sows and piglets in the experiment Tabela 4. Proizvodni rezultati krmača i prasadi u ogledu

\begin{tabular}{|c|c|c|}
\hline Group - Grupa & $\begin{array}{c}1 \\
\text { control - kontrolna } \\
\end{array}$ & $\begin{array}{c}2 \\
\text { experimental - ogledna }\end{array}$ \\
\hline \multicolumn{3}{|l|}{ Lactating sows - Krmače u laktaciji } \\
\hline $\begin{array}{l}\text { Ekofish meal during lactation in the diet } \\
\text { Ekofiš meal tokom laktacije u obroku }\end{array}$ & - & + \\
\hline $\begin{array}{l}\text { Body mass of sows before farrowing. } \mathrm{kg}^{*} \\
\text { Telesna masa krmača pre prašenja, kg }\end{array}$ & 227.2 & 228.8 \\
\hline $\begin{array}{l}\text { Body mass of sows at weaning. } \mathrm{Kg} \\
\text { Telesna masa krmača na zalučenju, kg }\end{array}$ & 192.7 & 192.7 \\
\hline $\begin{array}{l}\text { Average daily feed intake of sows. } \mathrm{Kg} \\
\text { Prosečna konzumacija hrane krmača, } \mathrm{kg}\end{array}$ & 3.76 & 3.66 \\
\hline $\begin{array}{l}\text { Losses of body mass of sows. before } \\
\text { farrowing to weaning } \% \\
\text { Gubici telesne mase krmača pre prašenja do } \\
\text { alučenja, \% }\end{array}$ & 15.23 & 15.78 \\
\hline Service period. days -Servis period, dana & 9,8 & 7,4 \\
\hline \multicolumn{3}{|l|}{ Suckling piglets Prasad na sisi } \\
\hline $\begin{array}{l}\text { Duration of lactation. days } \\
\text { Trajanje laktacije, dana }\end{array}$ & 28.4 & 28.4 \\
\hline $\begin{array}{l}\text { Number of egalized liveborn piglets/litter** } \\
\text { Broj egelizovane živorođene prasadi/leglo }\end{array}$ & 11.20 & 11.55 \\
\hline $\begin{array}{l}\text { Number of stillborn piglets/litter } \\
\text { Broj mrtvorođene prasadi/leglo }\end{array}$ & 0.20 & 0.30 \\
\hline $\begin{array}{l}\text { Number of weaned piglets/litter } \\
\text { Broj odbijene prasadi leglo }\end{array}$ & 9.00 & 9.00 \\
\hline $\begin{array}{l}\text { Average body mass of suckling piglets,kg } \\
\text { Prosečna telesna masa prasadi na prašenju, kg }\end{array}$ & 1.43 & 1.47 \\
\hline $\begin{array}{l}\text { Average body mass of piglets at weaning, } \mathrm{kg} \\
\text { Pros. Telesna masa prasadi na zalučenju, kg }\end{array}$ & 6.99 & 7.27 \\
\hline $\begin{array}{l}\text { Compared to the control group, } \% \\
\text { U poređenju sa kontrolnom grupom, } \%\end{array}$ & - & +4.01 \\
\hline $\begin{array}{l}\text { Average daily gain of suckling piglets, } g \\
\text { Pros. dnevni prirast prasadi u laktaciji, } g\end{array}$ & 197 & 208 \\
\hline $\begin{array}{l}\text { Compared to the control group, } \% \\
\text { U poređenju sa kontrolnom grupom, } \%\end{array}$ & - & +4.52 \\
\hline $\begin{array}{l}\text { The consumption of prestarter/litter. } \mathrm{Kg} \\
\text { Konzumirano predstartera/leglo, } \mathrm{kg}\end{array}$ & 8.61 & 9.61 \\
\hline
\end{tabular}

*) $1^{\text {st }}$ control group weighed 9.3 days. and $2^{\text {nd }}$ experimental one on 10.3 days before farrowing/ 1. kontrolna grupa je merena 9,3 dana a druga, ogledna grupa 10.3 dana pre prašenja.

**) After the colostrum consumed. the number of suckling piglets was unified/Posle posisanog kolostruma broj prasadi na sisi je ujednačavan 
There was no significant difference in regard to number of equalized number of live born, still born and weaned piglets between investigated groups of sows (table 4). During the lactation, utilization of investigated feedstuff in the mixtures for the trial group caused realization of better gain in piglets in average by $11 \mathrm{~g}$ or $4.52 \%$ compared to the control group of animals.

The main components of investigated high protein feedstuff of plant origin-Ekofish meal are soy bean protein isolates, as well as soy bean protein concentrate, full fat soy bean and soy bean meal (Adamović et al., 2006). Maribo (2001) stated that the fish meal can successfully be substituted with feed based on yeast.

In regard to soy bean products, hydrolyzed soy bean protein is excellent source of nutritive matters for piglets (Ferrini et al., 2004). Piglets fed the products based on soy bean proteins can progress equally to piglets fed diets containing the fish meal (Davis et al., 2000; Min et al., 2003; Sardi et al., 2005). Soy bean protein isolates can be good alternative (Ebert et al., 2004) and due to arginine even superior to whey protein (Ebert et al., 2005), although inferior than casein (Junghans et al., 2004), i.e. they can substitute up to $50 \%$ of proteins of skimmed powder milk (Junqueira et al., 2004) in the nutrition of piglets. Piglets fed diets containing soy bean protein isolates in the mixtures utilize the feed better and there are less diarrhea incidences (Jones et al., 1990; Kiers et al., 2003), and by measuring ileal digestibility they are superior to those fed the diets based on soy bean protein concentrate (Barriero et al., 2006).

Compared to soy bean meal, soy bean isolates have proven to be superior (Jones et al., 1990) because of better digestibility of lysine (Sohn et al., 1994) and better development of intestinal villus and cripta in small intestines (Li et al., 1990; Li et al., 1991) and this leads to improved the piglet production (Lenehan et al., 2003). Addition of lecithin and enzyme to diets based on soy bean meal could not reach the same level of feed utilization in weaned piglets fed the diets based on fish meal, with considerable increase of the cost of piglet gain (Kovčin et al., 2005).

Evidently the effect of introduction of plant protein sources depends on the percentage of their introduction into the mixtures, the processing method and age of pigs. Improved efficiency of utilization of plant proteins can be attributed to the adaptability of the system for digestion in pigs (Kidder and Manners, 1980). 


\section{Conclusion}

The effects of the use of plant high protein feedstuff - Ekofish meal in the nutrition of lactating sows and suckling piglets, were investigated. The obtained results showed that in iso-energetic and iso-protein diets introduction of investigated feedstuff had the following effects:

- No losses of body weight of sows during lactating period;

- Shorter service period by 2.4 days;

- $\quad$ Lower feed intake of the sows by $2.7 \%$;

- Better gain in the suckling piglets by $4.5 \%$;

In general, the obtained results demonstrate that the use of investigated domestic plant high protein feedstuff - Ekofish meal can be recommended in nutrition of sows and suckling piglets.

\section{Nutritvna vrednost Ekofiš meala u ishrani svinja}

B. Živković, W. Migdal, V. Veselinović, Č. Radović, M. Fabjan, O. Kosovac

\section{Rezime}

Ispitivani su efekti korišćenja Ekofiš meal-a, biljnog visokoproteinskog hraniva domaćeg porekla u ishrani krmača u laktaciji i prasadi na sisi.

Imajući u vidu naša ranija pozitivna iskustva pri korišćenju sličnog hraniva $u$ ishrani odbijene prasadi i svinja u tovu, kao i pozitivna iskustva o primeni Ekofiš meal-a kao supstituenta ribljeg brašna u ishrani svinja, cilj ovoga rada je bio da se oceni mogućnost njegovog korišćenja u smešama ujednačenim na sadržaj energije i sirovih proteina kod krmača u laktaciji i prasadi na sisi.

Ispitivano hranivo je proizvedeno po posebnoj tehnologiji $u$ proizvodnim pogonima kompanije Bankom u Srbiji.

Istraživanja su izvedena na Eksperimentalnoj farmi svinja u Institutu za stočarstvo, Beograd-Zemun.

Dobijeni rezultati su pokazali da je uvođenje ispitivanog hraniva imalo pozitivne efekte izražene kraćim servis periodom za 2,4 hranidbena dana, za 
$4,52 \%$ boljim prirastom kod prasadi na sisi i povećanom konzumacijom predstartera za $1,0 \mathrm{~kg} /$ leglo kod prasadi na sisi.

U celini, dobijeni rezultati su pokazali da se korišćenje Ekofiš meal-a može preporučiti u ishrani krmača u laktaciji i prasadi na sisi.

Ključne reči: Ekofiš meal - domaće visokoproteinsko hranivo biljnog porekla, krmača u laktaciji, prasad na sisi.

\section{Acknowledgements}

We would like to use this opportunity and thank the company Bankom, New Belgrade for the provision of high protein domestic feedstuff used in the trial.

\section{Literatura}

ADAMOVIĆ M., VESELINOVIĆ V., TOMOVIĆ R., VRANJEŠ B. (2006): Efikasnost korišćanja zamene za riblje brašno - Ekofish meal u ishrani prasadi po odbijanju. XVII Inovacije u stočarstvu. Biotehnologija u stočarstvu, Vol. 22, 669-677.

BARRIERO A. A.,MARIA. SOUZA T. C. R., LANDIN G. M., SOSA A. G. B., BARREYRO A. A. (2006): Digestibility of nutrients in piglets fed diets with isolated or concentrate soy protein. Téc. Pecu Méx., 44 (3), 301-311.

DAVIS M. E., BROWN D. C., MAXWELL C. V., JOHNSON Z. B., WALKER W. R., HAQUE A. K. M. H. (2000): Potential for an extruded multiple protein complex (Profound ${ }^{\mathrm{TM}}$ ) as a replacement for fish meal in early weaned pig diets. Journal of Animal Science, Vol. 78, Suppl. 1, 180.

EBERT A., BERMAN A.S., HARREL R.H., CORNELIUS S.G., ODLE J. (2004): M97 Liquid diets containing vegetable proteins accelerate piglet growth above milk-protein-based diets. Journal of Animal Science, Vol. 82, Suppl. 1, 24.

EBERT A., BERMAN A., HARREL B., CORNELIUS C., ODLE J. (2005): Vegetable Protein Sources for diets of Suckling Piglets. North Carolina State University, Animal Science Department Report.

FERRINI G., BORDA E.. MARTINEZ PUIG D., GARCIA-MANZANILLA E., MARTIN-ORUE S., PEREZ J. (2004). Influence of a soy protein hydrolizate on the productive performance of early weaned pigs under a 
enterotoxigenic E. Coli (ETEC) collibacilosis or under an healthy status. Journal of Animal Science, Vol. 82, Supplement1, 24.

HOORICK van H. (2003). Solutions for more strict feeding-regulations: Vitaprotein 50 - the vegetable replacer for fishmeal; aromabiotic - the natural replacer for the growth promoters. Biotechnology in Animal Husbadry, 19 (56), 367-373.

JONES D. B., HANDCOCK J. D., REDDY P. G., KLEMM R. D., BLECHA F. (1990): Effect of replacing dried skim milk with specially processed soy products on digestibility of nutrients and growth performance of nursery pigs. Swine day, Kansas State University, 37-40.

JONES D. B., HANDCOCK J. D., REDDY P. G., KLEMM R. D., BLECHA F. (1990): Effect of replacing dried skim milk with soy products on function and morphology of the small intestine in nursery pigs. Swine day, Kansas State University, 41-44.

JUNGHANS P., DERNO M.. JENTSCH W., KUHLA S., BEYER M. (2004): Effect of a soy protein diet on protein and energy metabolism and organ development in protein-restricted growing pigs. Arhiv of Animal Nutrition, 58 (6), 453-461.

JUNQUEIRA O. M., SILZ Z. T., LILIAM. ARAUJO L. F., LOPEZ E. L., DUARTE F. KARINA (2004): Substitution levels of dry skim milk for isolated soybean protein in diets for weaned pigs. Rev. Bras. Zootec., Vol. 33, $\mathrm{N}^{\mathrm{o}} 6$.

KIDDER D. E., MANNERS M. J. (1980): The level of distribution of carbohydrases in small intestine mucosa of pigs from 3 weeks of age to maturity. British Journal of Nutrition, 43: 141-153.

KIERS J. L., MEIJER J. C., NOUT M. J., ROMBOUTS M. J., NABUURS M. J., Van der MEULEN J. (2003). Effect of fermented soya beans on diarrhoea and feed efficiency in weaned piglets. Journal Applied Microbiology, 95 (3), 545-552.

KOVČIN S., STANAĆEV VIDICA, BEUKOVIĆ M., KOROLJEV Z.(2005): Efekti isključenja hraniva životinjskog porekla uz dodatak enzima na proizvodnju zalučene prasadi. Veterinarski Glasnik, Vol. 59, N ${ }^{\circ}$ 5-6, 683-686.

LENEHEN N. A., GOODBRAND R. D., TOKACH M. D., DRITZ S. S., EISSEN J. L., BARKER M. R., FRANTZ N. Z., GROESBECK C. N., IWASAWA T., KEEGAN T. P., LAWRENCE K. R. (2003). Evaluation of different soya protein concentrate source on growth performance of weanling pigs. Kansas State University, Swine Days, 1-4.

LI D. F., NELSSEN J. L., REDDY P. G., BLECHA F., KLEMM R. D., GOODBRAND R. D. (1990) Interrelationship between hipersensitivity to soybean proteins and growth performance in early-weaned pigs. Swine day, Kansas State University, 45-51. 
LI D. F., NELSSON J. L., REDDY P. G., BLECHA F., KLEMM R. D., GIESTING D. W., HANCOCK J. D., ALLEE G. L., GOODBRAND R. D. (1991). Measuring suitability of soybean products for early-weaned pigs with imunological criteria. Journal of Animal Science, Vol. 69, $\mathrm{N}^{\mathrm{o}}$ 8, 3299-3307.

MARIBO HANNE (2001). Comercial products for weaners: NuPro 2000 as an alternative protein source for weaners. The National Commitee for Pig Production. DANISH BACON \& MEAT COUNCIL, Report N ${ }^{\circ}$ 526, 23/8, 1-4. MIN B. J., KIM I. H., HONG J. W., KWON O. S., LEE W. B., SON K. S., KIM J. H., SHO W. C. (2003): Effect of feeding processed soy protein on the growth performance in weanling pigs. Journal of Animal Science, Vol. 81, Suppl. 1. 206.

SARDI L., PAGANELLI R., PARISINI P., SIMIOLI M., MARTELLI G. (2005). The replacement of fishmeal by plant proteins in piglet production. Italian Journal of Animal Science, Vol. 4, Supplement 2, 449-451.

SOHN K. S., MAXWELL C. V., SOUTHERN L. L., BUCHANAN D. S. (1994): Improved soybean protein sources for early-weaned pigs: II. Effects on ileal amino acid digestibility. Journal of Animal Science, Vol. 72, Issue 3, 631637.

ŽIVKOVIĆ B., PETROVIĆ MILICA, KOSOVAC OLGA, RADOVIĆ Č., FABJAN M. (2006): Effect of use of Vitaprotein 50 as fish meal substitute in nutrition of growing-fattening pigs. The $35^{\text {th }}$ International Session of Scientific Communications. The Scientific Papers of the Faculty of Animal Science, Bucharest, 171-175.

ŽIVKOVIĆ B., MIGDAL W., KOVČIN S., RADOVIĆ Č., KOSOVAC OLGA (2007): Effect of using plant protein feed as a fish meal replacer in the nutrition of weaned piglets. Annals of Animal Science. Kraków, Vol. 7, N ${ }^{\mathrm{o}} 2$, 273-278.

ŽIVKOVIĆ B., MIGDAL W., VESELINOVIĆ V., RADOVIĆ Č., KOSOVAC O., FABJAN M. (2007): The effect of substitution of fish meal with high protein plant feed in nutrition of sows and piglets. 2. Međunarodni Kongres o stočarstvu «Nove perspektive i izazovi održivog stočarstva», Country Club Hotel Babe, Sopot, 3-5 oktobar 2007. Biotechnology in Animal Husbandry, 23 (5-6), 445-455.

ŽIVKOVIĆ B., VESELINOVIĆ V., MIGDAL W., CILEV G., KOSOVAC O., RADOVIĆ Č., MARINKOV G. (2007): Ekofish meal as fish meal substitute in nutrition of weaned piglets and fattening pigs. III Symposium of Livestock Production with International Participation, Ohrid, 669-675. 